163

Received: July 6, 2012

Accepted: December 4, 2012
Macedonian Journal of Animal Science, Vol. 3, No. 2, pp. 147-151 (2013)

In print ISSN $1857-6907$

On line ISSN $1857-7709$

UDC: $636.32 / .38(560$

$637 ' 632 / 638(560)$

Original scientific paper

\title{
POTENTIALS AND PRESENCE OF SHEEP BREEDING AND PRODUCTS IN TURKEY
}

\author{
Halit Deniz Şireli ${ }^{1}$, Seyrani Koncagül ${ }^{2}$, Muhittin Tutkun ${ }^{1}$ \\ ${ }^{1}$ Department of Animal Science, Faculty of Agriculture, University of Dicle, Diyarbakir, 21100, Turkey \\ ${ }^{2}$ Department of Animal Science, Faculty of Agriculture, University of Harran, Sanliurfa, 63200, Turkey \\ hdsireli@gmail.com
}

\begin{abstract}
In this study, it was intended to present general information about the products status, breeding systems and to propose recommendations for improvement of the potentials about sheep breeding. Based on the agricultural statistics by FAO, there is an important potential in terms of sheep breeding, the number of animals and the production value. According to 2010 figures, $2.1 \%$ of the world sheep population is in Turkey with the presence of 21.8 million sheep. As a result, based on the continuous decrease in the presence of sheep in Turkey, there is a decrease of $10 \%$ sheep over the previous year in 2010. In 2010, there is an increase of $10 \%$ in terms of sheep milk, a decrease of $9.2 \%$ sheep and goat meat and a decrease of $27 \%$ in terms of wool production comparing to the previous year.
\end{abstract}

Key words: Turkey; sheep product; sheep breeding

\section{ПОТЕНЦИЈАЛИ И ЗАСТАПЕНОСТ НА ОВЧАРСТВОТО И ОВЧИТЕ ПРОИЗВОДИ ВО ТУРЦИЈА}

\begin{abstract}
Целта на оваа студија е да се презентираат општи информации за статусот на производите, системите на одгледување и да предложи препораки за подобрување на потенцијалите за одгледување на овци. Врз основа на земјоделските статистики од ФАО, постои значаен потенцијал во однос на одгледувањето на овци, бројот на животните и вредноста на производството. Според статистиката во 2010 год., 2.1\% од светската популација овци се одгледува во Турција, чиј број изнесува 21,8 милиони овци. Како резултат на тоа, врз основа на континуираното намалување, бројот на овците во Турција има пад од $10 \%$, во однос на претходната година. Во 2010 година е забележан пораст од $10 \%$ во однос на производството на овчо млеко, намалување од $9,2 \%$ во производството на овчо и козјо месо и намалување од $27 \%$ во однос на производството на волна, во споредба со претходната година.
\end{abstract}

Клучни зборови: Турција; овчи производ; овчарство

\section{INTRODUCTION}

Small ruminant breeding has great importance traditionally in the Turkish economy. As it is well known the small ruminants have an ability to process infertile pastures, fallow, stubble and unfit lands and can convert them into meat, milk, wool, fleece and leather. During the last two decades, the presence of small ruminants has decraesed continously and it has not been suported by increasing the yield per animal, and as a result, sheep products such as meat, milk, wool, hair, mohair and leather production hawe decreased. Economical and technical actions may be taken in consideration in order to increase the income of sheep breeders in Turkey (Kaymakç1 et al., 2009).

There are about 4 million agricultural enterprises in Turkey and $73 \%$ of them were occupied with crop production and animal production, and only $3 \%$ is dealing with animal production (Dellal et al., 2002). The holding size (head) in terms of small ruminants number, the number of holdings having sheep and goats and small ruminants rate are represented in Table 1. 


\section{Table 1}

Holding size (by head) in terms of small ruminants number, the number of holdings having sheep and goats and small ruminants rate (Anonymous, 2006)

\begin{tabular}{ccc}
\hline \hline $\begin{array}{c}\text { Holding size according to } \\
\text { number of sheep and goats } \\
\text { (head) }\end{array}$ & $\begin{array}{c}\text { Holdings having } \\
\text { sheep and goats }\end{array}$ & $\begin{array}{c}\text { Sheep and } \\
\text { goats }\end{array}$ \\
\hline Total & 100,0 & 100.0 \\
$1-4$ & 18,6 & 1.0 \\
$5-9$ & 10,8 & 1.6 \\
$10-19$ & 17,2 & 4.9 \\
$20-49$ & 25,3 & 16.8 \\
$50-149$ & 21,1 & 36.1 \\
$150-299$ & 5,6 & 24.1 \\
$300+$ & 1,5 & 15.6 \\
\hline \hline
\end{tabular}

\section{Current Sitiuation of Sheep Breeding in Turkey}

There are various sheep breeds and production methods in Turkey differing in terms of the food resources for small ruminants, natural conditions of regions and socio-economic characteristics, consumers' habits (Kaymakç1, 2006).

Feeding of sheep is primarily based on the pasture, fallow and stubble in Turkey and feeding of sheep and lambs is not sufficent depending on food resources. Early slaughtering (in west regions) and late slaughtering (in east regions) occur frequently. Health care is also insufficent. Selection of stud rams is done based on subjective criteria in breeding flocks. Selection based on the yield records is done in the State and Breeding Farms. Holding size is small and organized breeding is not performed as well. As a result of these structural characteristics, animal products obtained from sheep such as milk, meat, wool and lamb are unsatisfactory. The income of small ruminants breedings is not high due to the marketing organization in favour of the breeders.

There are various sheep breeds raising in terms of the regional conditions in Turkey: native sheep breeds are fat-tail breeds (Akkaraman, Morkaraman, Dağlıç and Awassi), thin-tail breeds (Kıvırcık, Karayaka, Sakız and Gökçeada), local fat-tail breeds (Tuj, Herik, Hemşin, Ödemiş, Çine Çapari and Norduz) (Anonymous, 2009). Furthermore, There are some types developed as a result of the sheep breeding researches such as wool type (Karacabey Merino, Malya, Anadolu Merino and Orta Anadolu Merino sheep), meat-wool type
(Ramliç and Menemen sheep) and milk type (Tahirova, Sönmez and Acıpayam sheep).

Small ruminant production systems in Turkey are performed as the Sedentary system (family enterprises/business, Agricultural enterprises and raising in village flocks), the transhumant system and a Nomadic System according to the regional conditions, in relation to food resources and plant production and consumers' habits.

The majority of local sheep breeds in Turkey are seasonally polyestrous and they lamb once a year. Ram usage during the breeding season is done by the method of continuous service in the raising herds and by hand mating service in breeding flocks. Matings take place within the following periods in different regions: September-October in Central Anatolia, October-November in Eastern Anatolia, August-September in southeastern Anatolia and Mediterranean and Black Sea Regions, July-August in Aegean Region and Thrace, and June-July in Southern Marmara Region. In general, flushing is not applied before mating, however flushing is done in breeding flocks that are applied the hand-service. Most of breeders prefer stubble grazing to flushing. Pregnancies last about 150 days later than mating in the region.

Most of sheep in Turkey are milked after weaning. Milking time and period depends on the region and the breed, which takes about 2-4 months. The milking period is longer (6 months) in Awassi and Sakiz milk-breeds. Sheep breeds raised in west-Anatolia and Trace are milked longer than breeds raised in middle and eastern Anatolia. Animals are milked by hand.

Shearing is done by the blade shears in the period when the fleece grease starts melting at $35^{\circ} \mathrm{C}$. Machine shears are generally used in the State or private breeding flocks. Breeders shear their animals once a year. Shearing time differs from region to region of the country. Shearing of sheep takes place in April-May in the west part of Turkey, May-June in the middle part of Turkey and June-July in eastern Turkey. However, in some sheep flocks of Awassi, Karayaka and Imroz breeds shearing is also practiced twice-a-year.

The feeding of ewes and rams during the grazing season depends almost completely on pastures and cereal stubbles. The grazing season generally starts in the beginning of February and ends towards the end of November in the middle, east and south part of Turkey. Pasture quality is poor in the middle and south-Anatolia. In general, the number of holdings having supplementary feeding is less after grazing. 
The feeding of lambs differs depending on production systems and regional conditions. Lambs are housed with ewes in the first month after lambings and taken to the pasture in the second month. Lambs are weaned 1.5-4 month of age. The Weaning period in the west part is shorter than in the middle and east part of Anatolia. Lamb fattening is performed as intensive and semi-intensive systems in the west part of Turkey. In the middle and eastern regions, the extended lamb fattening is more common. Marketing age of lambs ranges 3-3.5 months in the west and 6-7 months in the eastern region. In generally, shelter is used for housing of animals in sedentary and transhumant systems, The shelter is simple and often unhygienic, and made of stone, bricks, mud bricks or wood depending on the availability of these materials. Animals are not housed in the region in which the nomedic system is performed and the animals are housed in a suitable place during the year.

Trends in the number of sheep between the years from 2006 to 2010 are represented in Table 2. The presence of sheep increased $6.33 \%$ in Africa while it declined in Europe, America and Asia, conversely. The highest number of sheep is in Asia with 453843000 head and the least number of sheep is in America with 93282898 heads

Table 2

Trends in number of Sheep (head) in continents(Anonymus, 2010-b)

\begin{tabular}{lccc}
\hline \hline Continent & 2006 & 2010 & Change (\%) \\
\hline Europe & 137049644 & 130710094 & -4.62 \\
USA & 95148356 & 93282898 & -1.96 \\
Asia & 460708967 & 453843099 & -1.49 \\
Africa & 282543432 & 300448070 & +6.33 \\
Auustralia & 131141840 & 100664040 & -23.24 \\
World & 1106592239 & 1078948201 & -2.49 \\
\hline \hline
\end{tabular}

The top 5 countrieswhil the greatest number of sheep in the period from 2006-2010 in the world are shown in Table 3. While the number of sheep has increased in Chine and Australia, 12.9\% and $33.7 \%$, respectively, the number of sheep has declined in other countries. Turkey among sheep raising countries of the world has a sheep population of 25.3 million head, with $2.01 \%$ of world's sheep population.
Table 3

Trends in number of Sheep (head) in the world (Anonymous, 2010-b)

\begin{tabular}{lccc}
\hline \hline Country & 2006 & 2010 & Change (\%) \\
\hline China & 134021213 & 151337213 & +12.9 \\
Auustralia & 68085500 & 91028400 & +33.7 \\
India & 73991000 & 68885000 & -6.90 \\
Iran & 54000000 & 53800000 & -0.37 \\
Sudan & 52014100 & 50390000 & -3.12 \\
Turkey & 25304300 & 21794500 & -13.87 \\
World Total & 1106592239 & 1078948201 & \\
\hline \hline
\end{tabular}

The top 5 countries with the greatest number of sheep in the period from 2006 to 2010 in Europe are shown in Table 4, respectively. While the number of sheep increased by $1.98 \%$ in Greece, the number of sheep has declined $91.7 \%$ in Spain during the same years. Turkey takes the second place by the presence of sheep in Europe with $16.67 \%$ of sheep population in Europe in 2010.

\section{Table 4}

Trends in number of sheep(head) in Europe (Anonymous, 2010-b)

\begin{tabular}{lccc}
\hline \hline Country & 2006 & 2010 & Change (\%) \\
\hline UK & 34722000 & 31000000 & -10.71 \\
Turkey & 25304300 & 21794500 & -13.87 \\
Spain & 22451600 & 1855160 & -91.73 \\
Greece & 8791760 & 8966000 & +1.98 \\
Italy & 7954000 & 8012600 & +0.73 \\
Europe Total & 137049644 & 130710094 & \\
\hline \hline
\end{tabular}

The top five countries producing sheep meat in the period from 2006 to 2010 in the World are represented in Table 5, respectively. While the maximum increase in meat production is seen in New Zealand with $15.13 \%$, the maximum decrease is in Sudan with $13.18 \%$. Chine leads the world in producing sheep meat with 1938000 tons. The least sheep meat production was in Sudan with 349 000 tons. Turkey constituted $3.03 \%$ of the world sheep meat production in 2010.

The top five countries producing meat in the period from 2006 to 2010 in Europe are represented in Table 6. While the UK is the first in pro- 
ducing sheep meat with 280861 tons, Greece is the last with 89320 tons. Rapid increase in meat production is seen in France with $22.53 \%$. The largest decrease was in Spain with $38.72 \%$ in the period between 2006 and 2010.

\section{Table 5}

\section{Sheep Meat Production (ton) in World} (Anonymous, 2010-b)

\begin{tabular}{lccc}
\hline \hline Country & 2006 & 2010 & Change (\%) \\
\hline China & 1938000 & 2070000 & +6.81 \\
Auustralia & 555616 & 625629 & +12.60 \\
New Zealand & 470906 & 542191 & +15.13 \\
Iran & 360000 & 330000 & -8.33 \\
Sudan & 349000 & 303000 & -13.18 \\
Turkey & 288161 & 259000 & -10.11 \\
World Total & 8276007 & 8532257 & +3.09 \\
\hline \hline
\end{tabular}

The top five countries in milk production in the period from 2006 to 2010 in the World are represented in Table 7. China is the first in producing milk with 1724000 tons and a rapid increase in milk production is also seen in China with $58.02 \%$ as well. Romania is less increasing with $0.08 \%$. Turkey supplied $8.13 \%$ of the world sheep milk production in 2010.

The top five countries in producing milk in the period from 2006 to 2010 in Europe are given in Table 8 . While more rapid increase in milk production is seen in Spain for ythe same period with $37.91 \%$ the least increase is in Romania with $0.08 \%$. Turkey with supplied $26.35 \%$ of sheep milk production in Europe in 2010.

\section{Table 6}

\section{Sheep Meat Production(ton) in Europe (Anonymous, 2010-b)}

\begin{tabular}{lccc}
\hline \hline Country & 2006 & 2010 & Change (\%) \\
\hline UK & 330069 & 280861 & -14.90 \\
Turkey & 288161 & 259000 & -10.11 \\
Spain & 214179 & 131231 & -38.72 \\
France & 99447 & 121861 & +22.53 \\
Greece & 94340 & 89320 & -5.32 \\
Europe Total & 1166967 & 1271055 & +8.91 \\
\hline \hline
\end{tabular}

Table 7

Sheep Milk Production(ton) in World (Anonymous, 2010-b)

\begin{tabular}{lccc}
\hline \hline Country & 2006 & 2010 & Change (\%) \\
\hline China & 1091000 & 1724000 & +58.02 \\
Greece & 753470 & 855000 & +13.47 \\
Turkey & 794681 & 816832 & +2.78 \\
Italy & 548299 & 600100 & +9.44 \\
Romania & 650790 & 651317 & +0.08 \\
World Total & 9280978 & 10046506 & +8.24 \\
\hline \hline
\end{tabular}

Table 8

Sheep milk production(ton) in Europe (Anonymous, 2010-b)

\begin{tabular}{lccc}
\hline \hline Country & 2006 & 2010 & Change (\%) \\
\hline Greece & 753470 & 855000 & +13.47 \\
Turkey & 794681 & 816832 & +2.78 \\
Romania & 650790 & 651317 & +0.08 \\
Italy & 548299 & 600100 & +9.44 \\
Spain & 424300 & 585190 & +37.91 \\
Europe Total & 3377789 & 3098878 & -8.25 \\
\hline \hline
\end{tabular}

The top five countries in producing wool in the World are represented in Table 9. Rapid increase in wool production was seen in the UK with $16.41 \%$ in the period between 2006-2010. The most declining production was seen in Auustralia and New Zealand with $26.46 \%$ and $26.21 \%$, respectively. Wool production of Turkey deacresed for $36.50 \%$ during the same years. Turkey produced $1.45 \%$ of the world's wool production in 2010 .

Table 9

Wool production (ton) in the world (Anonymous, 2010)

\begin{tabular}{lccc}
\hline \hline Country & 2006 & 2010 & Change (\%) \\
\hline China & 388777 & 386768 & -0.51 \\
Auustralia & 519900 & 382300 & -26.46 \\
New Zealand & 224700 & 165800 & -26.21 \\
UK & 57552 & 67000 & +16.41 \\
Morocco & 48873 & 55300 & +13.15 \\
Turkey & 46776 & 29700 & -36.50 \\
World Total & 2249472 & 2043434 & -9.15 \\
\hline
\end{tabular}


The top five countries in producing wool in Europe are represented in Table 10. The UK is the first by producing 67.000 ton wool in 2010. More rapid increase in wool production was seen in the UK for $16.41 \%$ in the period between 2006-2010. The most declining production was seen in Turkey for $36.50 \%$. Turkey produced $11.41 \%$ of Europe's wool production in 2010 .

Table 10

Wool Production (ton) by years (Anonymous, 2010-b)

\begin{tabular}{lccc}
\hline \hline Country & 2006 & 2010 & Change (\%) \\
\hline UK & 57552 & 67000 & +16.41 \\
Russia & 50276 & 53280 & +5.97 \\
Turkey & 46776 & 29700 & -36.50 \\
Spain & 30387 & 28000 & -7.85 \\
Romania & 19378 & 17600 & -9.17 \\
Europe Total & 251376 & 260239 & +3.52 \\
\hline \hline
\end{tabular}

\section{Basic Problems of Sheep Breeding in Turkey}

- Most farms are family owned enterprises with small capital. scale.

- Lack of a breeding strategy on a national

- Extensive production system and feeding supplemented only in winter.

- Grazing areas were reduced.

- Over grazing of current pastures.

- Unsuitable sheep barns.

- Intensive emigration from rural areas to big settlements, the number of people involved in agriculture declined.

- Difficulties in finding shepherds.

- Illegal slaughtering of ewes.

- Disinformation campaigns on sheep meat.

- Keeping permanent grazing land and dry steppe areas with poor nutritive.

\section{RESULTS AND RECOMMENDATIONS}

Factors affecting the development of animal production in Turkey are such as breeding, animal nutrition, dealing with animal diseases, organization and marketing, training, supporting policy and accession to financial sources.

Sheep enterprises must be supported and production must be encouraged for the purpose of development of the small ruminant breeding. The flocks with high-yielding foreign breeds or their cross-breeds must be comprised, precautions must be taken against animal diseases. Using quality forage and compound feed and silage must be encouraged, an alternative feed production must be widespread to supply current feed deficiency and increase the feed quality, training and seminars must be given to the sheep breeders to improve their skills and knowledge on the sheep production. Sheep Breeders must be supported to organize in cooperative or Breeders Associations the agricultural credit regulation must be revised to be achieved by the breeders conveniently.

In the light of knowledge attained, even though Turkey has a great potential for small ruminant breeding, the production performance is rather low. In order to improve the present situation, common strategies and future projections must be conducted by all private and governmental institutions working in the agricultural sector. Great importance and consideration must be given to the small ruminant breeding.

\section{REFERENCES}

[1] Anonymus (2006): Türkiye İstatistik Kurumu Hayvan İstatistikleri. http://www.TUIK.gov.tr.

[2] Anonymus (2010-a): Türkiye İstatistik Kurumu Hayvan İstatistikleri http://www.TUIK.gov.tr.

[3] Anonymus (2010-b): Food and Agriculture Organization of The United Nations. Live Animal Stat. http://faostat.fao.org

[4] Dellal, G., Eliçin, A., Tekel, N., Dellal, I. (2002): GAP Bölgesinde Küçükbaş Hayvan Yetiştiriciliğinin Yapısal Özellikleri. Proje Raporu 2002-1 Temmuz Ankara

[5] Ertuğrul, M. Cengiz, F. (1997); Hayvan Yetiştirme Ders Kitab1 2. Baskı. Koyun Yetiştiriciliği, Keçi Yetiştiriciliği Bölümü. Ankara 1997.

[6] Kaymakçı, M. (2006): İleri Koyun Yetiştiriciliği. Ders Kitab1. Bornova, İzmir.

[7] Kaymakçı, M., Özder, M:, Karaca, O., Torun, O., Baş, Sinan, Koşum, N. (2009): Türkiye Koyun Islah Stratejisi. U. Ü. Ziraat Fakültesi Dergisi, 2009, Cilt 23, Sayı 2, 6777 (Journal of Agricultural Faculty of Uludag University). 